\title{
Ursinus, die opsteller van die Heidelbergse Kategismus, Olevianus en die Heidelbergse teologie
}

\author{
JJ Steenkamp \\ Universiteit van Pretoria
}

\begin{abstract}
Ursinus, composer of the Heidelberg Catechism, Olevianus and the Heidelberg theology
\end{abstract}

Apart from a survey of the history of the Reformation in Heidelberg and the introduction of Calvinism to the Palatinate, this article concentrates on the contribution of Ursinus and Olevianus to the founding of the socalled Heidelberg theology. The Heidelberg Catechism may be regarded as a summary of the Heidelberg theology. The covenant theology of Ursinus and Olevianus provides the starting point of the Foederaltheologie of later times. As such it represents a bridge between Calvin and the subsequent calvinistic scholastics, but without providing any of the philosophical-speculative premises which are characteristic of the scholastics.

\section{HISTORIESE OORSIG}

\subsection{Die Hervorming in Heidelberg}

Heidelberg was een van die eerste stede wat deur die Hervorming van Martin Luther aangeraak is. Op 26 April 1518 het Luther daar, tydens 'n algemene vergadering van die Augustynerorde, as voorsitter opgetree by die gebruiklike akademiese dispuut. Vir die geleentheid het hy veertig stellings opgestel waaroor hy Leonhard Beier laat disputeer het. In die stellings het Luther sy theologia crucis ontwikkel wat met vriendelike skerpsinnigheid deur die Heidelbergse teoloë ontvang is. Hy het die dispuut met akademiese bekwaamheid oorheers en veral indruk gemaak op die jonger geslag teoloë.

Luther se optrede het 'n blywende uitwerking in Heidelberg gehad deurdat hy 'n 
aantal van die jonger manne vir die Hervorming gewen bet. Onder hulle was Martin Bucer, hofprediker van die keurvors se broer, die paltsgraaf Frederik, asook Johannes Brenz wat as magister in Heidelberg lesings gegee het. Beide manne het van die kansel en die kateder Luther se leiding gevolg en is spoedig deur ander bygestaan.

Die Heidelbergse hervorming het egter onbeslis gebly totdat keurvors Frederik Il in 1546 onder aansporing van sy neef Otto Hendrik openlik tot die Hervorming oorgaan. Die oorwinning vir die Hervorming was egter van korte duur, want in 1548 word Frederik II wel deur die keiser vergewe vir sy aandeel aan die Smalkaldiese Oorlog, maar gedwing om die Augsburgse Interim in die Palts in te voer.

Otto Hendrik volg Frederik II in Februarie 1556 as keurvors op en begin twee dae na sy aankoms in Heidelberg (Maart 1556) met 'n grondige hervorming. Hy kon hom beroep op die Augsburgse godsdiensvrede van die vorige jaar. Soos sy voorganger laat hy hom veral lei deur Melanchton. Hy suiwer die kerk van RoomsKatolieke gebruike en voer 'n nuwe kerkorde, hervormde eredienste en die Confessio Augustana in. Die kerkregering word opgedra aan 'n kerkraad waarop hy onder andere die bekwame hoogleraar in geneeskunde, Thomas Erastus, aanstel.

Die Hervorming word ook uitgebrei na die universiteit en die skole met die aanstelling van hervormde professore en onderwysers. Petrus Boquinus uit Frankryk, Paulus Unicornius uit Nortlingen en Tileman Heszhusius word as professore in die teologie benoem. Heszhusius het in Wittenberg promoveer en is sterk deur Melanchton aanbeveel.

Hoewel Heidelberg 'n Lutherse hervorming ondergaan het, was dit eintlik Melanchton wat die gang van sake grootliks beïnvloed het. Frederik II het sy hervormings ook op raad van Melanchton deurgevoer en persone op sy aanbeveling aangestel; so ook Otto Hendrik wat 'n persoonlike vriend van Melanchton was. Melanchton was self in Oktober 1557 in Heidelberg om raad te gee met die veranderinge aan die universiteit. Op hierdie besoek is hy onder andere deur Zacharias Ursinus vergesel wat indertyd in Wittenberg studeer het. Heidelberg was in hierdie stadium onaangeraak deur die onderlinge leergeskille van die Reformatore. Die vredeliewende gees van Melanchton het daar geheers en Lutherane, Calviniste en Zwingliane het in eensgesindheid met mekaar saamgeleef.

Kort hierna breek daar egter 'n onverkwiklike twis tussen die groepe uit. Aanvanklik kan onderskei word tussen streng Lutherane, meer toegeeflike Philippiste en Calviniste. Later word dit 'n getwis tussen Lutherane en Calviniste met Heszhusius en Klebitz as die onderskeie aanvoerders. Beide persone was strydvaardige karakters en het deur hulle optrede groot onmin veroorsaak. Aanvanklik woed die stryd oor die kategismus en die gesangboek, maar ontwikkel spoedig in 'n nag- 
maalstryd.

Otto Hendrik het die begin van die onverkwiklikhede nog beleef. Hy word in 1559 deur Frederik III, paltsgraaf van Simmern, as keurvors opgevolg. Frederik III tref Heidelberg in die grootste verwarring aan. Na mislukte vredespogings onthef hy sowel Heszhusius as Klebitz van hulle ampte en herstel die rus met 'n verandering van die kerkraad. Hierop vra hy raad by Melanchton wat met 'n kompromisvoorstel antwoord. Hy beveel aan dat 'n nagmaalsformulier gevind word wat albei partye met 'n geruste gewete kon gebruik en stel volgens die woorde van Paulus die volgende sin voor: Die brood wat ons breek, is die gemeenskap met die liggaam van Christus. Verdere vrae oor hoe die brood die gemeenskap was, moes nie in die gemeente behandel word nie.

Die kompromis het, soos te verwagte, nie die verlangde vrede bewerk nie. Frederik III besluit vervolgens om die aangeleentheid deur godgeleerdes te laat beslis. Sy raadgewer, Melanchton, is intussen oorlede. Na aanleiding van die huwelik van sy dogter Dorothea Susanna met hertog Johann Wilhelm van SakseWeimar, reël Frederik Ill op 3 Junie 1560 'n dispuut te Heidelberg tussen sy eie teoloë en die Lutherane van Sakse-Weimar. Petrus Boquinus en Thomas Erastus kom teen Maximiliaan Mörlin en Johannes Stössel te staan.

Boquinus het 24 stellings opgestel waarin hy die Calvinistiese nagmaalsleer uiteensit. Aangesien Boquinus probleme met Duits ondervind, staan Erastus hom by. Erastus wat die kuns verstaan het om die Lutherse teenstanders in 'n hoek te dryf, maak 'n baie groot indruk op Olevianus. Belangriker is egter dat die dispuut Frederik III met oortuiging vir die Calvinisme laat kies. Hy beslis dat die Calvinistiese teoloë die oorwinning behaal het.

Frederik 111 was 'n vroom en godsdienstige persoon wat deur studie sy eie teologiese kennis baie verbreed het. Met ywer lê hy hom nou daarop toe om die Palts na die voorbeeld van Genève in die gees van Calvyn te hervorm.

Die hervormings raak soos by sy voorgangers tegelykertyd die kerk, die universiteit en die skole. Die kerkraad waar die gereformeerde Erastus, Boquinus en Ehem leiding gee, word al meer 'n instrument van die gereformeerdes. Al die Roomse oorblyfsels en Lutherse seremonies word uit die kerk verwyder en met Calvinistiese gebruike vervang. Frederik III versterk die universiteit met die aanstelling van Calvinistiese teoloë, naamlik Tremellius, Olevianus, Brunner en later Ursinus. Om die kerkvolk deur middel van die kategese en die skole in die Calvinistiese leer te onderrig, gee hy opdrag dat 'n kategismus opgestel word. Volgens tradisionele beskouing het hy die opdrag aan Ursinus en Olevianus gegee en hulle het dit uitgevoer. Navorsers verskil egter oor die geldigheid van dié beskouing (Metz 1988: 582-583). Met die aanvaarding van die Heidelbergse Kategismus op 19 
Januarie 1563 en die nuwe kerkorde op 15 November 1563 word die Calvinistiese hervorming in die Palts gevestig.

Die Hervorming in die Palts het dus besonder rustig verloop in vergelyking met ander plekke. Die Palts was indertyd die enigste vorstedom in Duitsland wat die Calvinisme aanvaar het. Frederik III het gevolglik dadelik met teenstand van Roomse sowel as Lutherse kant te doen gekry. Hy is gedreig dat sy Calvinistiese belydenis nie inbegrepe was in die vredesvoorwaardes van Augsburg 1555 nie, aangesien dié vrede primêr betrekking gehad het op Lutherane en Roomses. Deur sy persoonlike belydenis en optrede op die Augsburgse ryksdag van 1566 slaag Frederik III egter daarin om die vorste te beweeg om hom sy belydenis te gun en hom binne die godsdiensvrede te aanvaar. Met hierdie aanvaarding word die eerste periode in die Hervorming van die Palts afgesluit (Wesel-Roth 1954: 43). Ursinus en Olevianus is in hierdie tyd Frederik III se belangrikste teologiese kampvegters. Hulle kom dus in Heidelberg aan in 'n stadium toe die Calvinistiese leer net oorwin het en neem deel aan die vestiging en die uitbouing daarvan. Om hulle rol na waarde te kan skat, moet 'n oomblik kortliks gelet word op hulle lewensgeskiedenis.

\subsection{Caspar Olevianus 1536-1587}

Olevianus word op 10 Augustus 1536 in Trier gebore waar hy ook skoolgaan. Op dertienjarige ouderdom begin hy sy universiteitstudie in Parys, sit dit voort in Orleans en Bourges en ontvang op 6 Junie 1557 'n doktorsgraad in die regte. Gedurende sy studentejare in Frankryk word hy vir die Hervorming gewen waar hy aansluit by die geheime Hugenotegemeentes. Hy raak bevriend met Lodewyk, seun van keurvors Frederik III van die Palts. Toe sy vriend in sy teenwoordigheid verdrink en hy self gered word, lê hy 'n gelofte af dat hy die evangelie in sy vaderland sal gaan verkondig.

Hierna ontvang hy teologiese opleiding in Genève, Zürich, Lausanne en weer Genève. Hy kom in aanraking met die belangrikste Switserse hervormers, naamlik Calvyn, Bullinger, Viret, Beza, Farel en Martyr. By Bullinger leer hy preek en sy belangrikste teologiese leraars is Calvyn en Martyr. In Genève vertaal hy die Geneefse kategismus van Calvyn in Duits wat aandui dat hy hom grootliks met Calvyn se teologiese beskouings vereenselwig het.

- Op 26 Junie word hy onderwyser in Trier waar hy filosofie aan die hand van Melanchton se dialektiek doseer. Hy begin op 10 Augustus 1559 in die studentehuis preek, maar word dadelik deur die biskoplike beampte verbied. Die stadsraad beskerm hom egter en laat hom toe om in die kapel van die St Jakobs-hospitaal te preek. Hier versamel gou 'n gemeente rondom Olevianus, maar die ontwikkelende Hervorming word deur die aartsbiskop onderdruk. Olevianus word vrywillig ge- 
vange geneem en daarmee eindig die Hervorming in Trier.

Frederik III van die Palts tree vir Olevianus in en na sy vrylating word hy na Heidelberg beroep waar hy in Januarie 1560 begin lesings gee aan die Sapienzkollege. In 1561 promoveer hy tot doktor in die teologie en word angestel as professor in dogmatiek aan die Universiteit van Heidelberg. $\mathrm{Na}$ ' $\mathrm{n}$ jaar le hy egter die amp neer en word predikant van die belangrikste gemeente in Heidelberg, die Heilig-Geist-Kirche. Hier aanvaar hy die amp van superintendent en word lid van die kerkraad. In hierdie hoedanigheid het hy 'n leidende aandeel aan die gestaltegewing van die Calvinistiese kerk van die Palts. Veral met die opstel van die uitgebreide kerkordelike maatreëls het sy regsopleiding goed te pas gekom. Met sy uitstaande organisatoriese bekwaamhede het hy in die kerkordenende werk 'n groter opdrag en vervulling gevind as agter die kateder. Na die aanvaarding van die Heidelbergse Kategismus het Olevianus hom daarop toegelê om die kerk selfstandig en onafhanklik van die owerheid te vestig. Soos in Calvyn se geval, was die belangrikste saak in die onafhanklikheidstrewe die onafhanklikheid van die kerklike tug. Ook soos in die geval van Genève kon hy slegs gedeeltelik daarin slaag (WeselRoth 1954: 63).

Met die oorlye van Frederik III in 1576 volg die Lutherse Lodewyk VI sy vader op en begin dadelik om die kerk te verluthers. Olevianus wat die leidende kerkman is, word afgesit. Graaf Lodewyk van Wittgenstein nooi hom na Berleburg waar hy van 1577-1584 leef en werk. Hier voer hy 'n selfstandige presbiteriaal-sinodale stelsel van kerkregering in. In 1584 word hy professor in die dogmatiek te Herborn. Ook hier voer hy die presbiteriaal-sinodale stelsel in. Op akademiese gebied gee hy vorm aan sy verbondsteologie. Hy sterf in 1587 te Herborn. Ter herdenking aan sy dood het die stadsbiblioteek van Trier vanjaar (1987) 'n groot uitstalling oor Olevianus gehou (Franz 1987).

\subsection{Zacharias Ursinus (Bār) 1534-1583}

Ursinus word op 18 Junie 1534 te Breslau gebore. Onder leiding van sy vader Andreas Beer, Moibanus en Winkler vorder hy so vinnig dat hy reeds op sestienjarige ouderdom die Universiteit van Wittenberg besoek. Hier studeer hy sewe jaar onder Melanchton met wie hy 'n sterk vrienskapsband sluit. Hy gaan as een van Melanchton se vertrouelinge saam na die godsdiensgesprek te Worms in 1557 waar hy van die beste teoloë van sy tyd ontmoet. Saam met Melanchton besoek hy in dieselfde jaar Heidelberg waar Melanchton raad gee oor veranderinge aan die Universiteit.

Vanaf Heidelberg vertrek hy na Straatsburg, Basel, Lausanne en Genève, waar hy Bucer, Bullinger en Calvyn leer ken. Hierna woon hy lesings van die hebraïs 
Mercier in Parys by. Hy keer terug na Switserland waar hy Martyr ontmoet en sy vrienskap met Calvyn en Beza hernuwe en versterk. Sy verhouding met Calvyn het so sterk ontwikkel dat laasgenoemde aan hom sy werke met inskrifte geskenk het. Hier word hy ook heeltemal vir die Calvinistiese leer gewen.

Terug in Duitsland word hy rektor van die Elizabeth-gimnasium in Breslau. $\mathrm{Hy}$ lê die amp neer na 'n heftige geskil met die Lutherane oor sy Calvinistiese nagmaalsopvatting. Op 3 Oktober 1560 kom hy weer in Zürich aan waar hy van voorneme was om te bly. Nadat Petrus Martyr self 'n beroep na Heidelberg bedank het, vestig hy die keurvors se aandag op Ursinus. Ursinus word na Heidelberg beroep. Nadat hy op 25 Augustus 1562 promoveer, volg hy Olevianus as professor in dogmatiek op.

Anders as Olevianus het hy hom op die akademiese werk toegelê en met ywer en sukses die Calvinistiese hervorming van Frederik III help vestig. In 1576 word hy ook deur Lodewyk VI afgesit en uit Heidelberg verban. Hy vind 'n nuwe werkkring in Neustadt an der Hardt, waar hy saam met ander afgesette teoloë 'n florerende teologiese skool onder beskerming van Johan Casimir, die tweede seun van Frederik III, vestig. Casimir was soos sy vader 'n Calvinis. Op 6 Maart 1583 sterf Ursinus in die fleur van sy lewe (Schaff 1919: 533).

\section{DIE HEIDELBERGSE TEOLOGIE, URSINUS EN OLEVIANUS}

Die Hervorming het in Heidelberg as 'n Lutherse beweging begin. Dit was 'n volksbeweging wat deur die predikante en die akademici gelei is. Die keurvors, Lodewyk die Vreedsame, het die ontwikkeling sien plaasvind sonder om dit aan te help en 'n lid van die Rooms-Katolieke Kerk gebly sonder om hom te beskerm. So gebeur dit dat die Lutherse teologie geleentheid vind om goed onder die gelowige kerkvolk gevestig te raak.

Onder Frederik II wat op 3 Januarie 1546 na die Hervorming oorgaan, word die Hervorming in die Palts 'n saak wat deur die owerheid deurgevoer word. Dit geskied in 'n verhoogde mate in die tyd van sy opvolger, Otto Hendrik, wat 'n goeie vriend en aanhanger van Melanchton was. Tot met sy dood in 1560 het Melanchton die teologiese raadgewer van die Palts gebly. Die Hervorming wat Frederik III deurvoer, dra eerder die minder strenge karakter van Melanchton as die kompromisloosheid van Luther. So was die nagmaalsopvatting wat in die Palts gegeld het nie die skerp consubstansiasie van die Confessio Augustana van 1530 nie, maar die gekompromitteerde opvatting van die C A Variata van 1540. Wanneer Melanchton in 1557 in Heidelberg kom om raad te gee met die veranderinge aan die Universiteit, het hy reeds ooreenstemming bereik met Calvyn oor die nagmaal hoewel dit nie 
algemeen bekend was nie (Schwarz 1962: 972).

Heidelberg was in hierdie stadium reeds beset deur die gereformeerde Christoffel Ehem en die bekwame medikus Thomas Erastus. Otto Hendrik toon ook sy gereformeerde oortuigings deur nie ag te gee op die waarskuwings van Brenz nie, maar voort te gaan om teoloe veral in Zürich te soek. Hy stel Petrus Boquinus aan wat, hoewel Calvyn nie 'n hoë dunk van hom gehad het nie, tog 'n aanhanger van laasgenoemde was.

Erastus was aanvanklik baie terughoudend oor sy belydenis en kon as medikus daarin slaag om tussen die gevaarpunte deur te beweeg. In die begin van Frederik III se regeringstyd kom hy egter tydens die Sylvius-saak na vore as die leidende figuur van die gereformeerdes (Wesel-Roth 1954: 20). Hy het teologie as ' $n$ liefhebbery bedryf maar het daarin nogtans 'n hoë bekwaamheid bereik. Onder sy leiding verander die teologiese klimaat van 'n Philippistiese na 'n Calvinistiese. Erastus het lewenslank 'n goeie verhouding met Bullinger gehandhaaf en het gevolglik daarna gestrewe om mense van Zürich na Heidelberg te beroep. Die verhouding tussen Erastus en Calvyn was een van wedersydse respek en hoogagting. Die rede waarom hy eerder op Zürich as op Genève sy hoop gevestig het, kan slegs in die taalfaktor geleë wees. Hy moes alreeds die Franssprekende Boquinus in teologiese strydvrae ter syde staan en kon hulp van Duitssprekende Calviniste goed gebruik. Daarom was die aanstelling van Olevianus en Ursinus in Heidelberg 'n tydige en gepaste optrede.

Olevianus en Ursinus kom in Heidelberg aan in 'n stadium toe hulle hulp dringend nodig was om kerk en teologie in die Palts na die Calvinistiese leer te vorm. Frederik III het wel met die dispuut oor die nagmaal beslis dat die Calvinisme die aanvaarbare leer was, maar selfs binne die kerkraad was dit nog nie heeltemal duidelik wat aan die gebeur was nie. Die probleem was dat Frederik III se Calvinistiese hervorming soos dié van sy twee voorgangers 'n Hervorming van bo af was wat nog nie onder die kerkvolk voet gevind het nie. Frederik III was daarvan bewus en hy het die voordeel wat hy gehad het in 'n Calvinisties-gesinde teologiese fakulteit en kerkraad goed benut. Sy probleem was egter 'n tekort aan prerikante en veral die feit dat daar geen eenvormigheid van kerkorde en kategesemateriaal in die Palts bestaan het nie.

Wanneer Olevianus en Ursinus dus in Heidelberg begin werk, was daar geen sprake van 'n eenvormige Heidelbergse teologie nie. Die algemene opvatting was gereformeerd met 'n oorwig na die Calvinisme eerder as die Zwinglianisme, terwyl onder die kerkvolk 'n Philippistiese Lutheranisme geheers het.

Frederik III se opdrag dat 'n kategismus en 'n kerkorde opgestel word wat die Calvinistiese leer moet saamvat en implementeer het die moontlikheid daargestel 
om 'n eenvormige leer en kerkregering in die Palts in te voer. Dit het ook die moontlikheid gebied om 'n eenvormige Heidelbergse teologie daar te stel.

Volgens die jongste stand van die navorsing was Ursinus hoofsaaklik verantwoordelik vir die voorbereiding van die Heidelbergse Kategismus (Metz 1985: 582 583). Wanneer 'n sinode in Heidelberg die Heidelbergse Kategismus op 13 Januarie 1563 sonder enkele wysigings aanvaar, is dit terselfdertyd 'n aanduiding van die aanvaarbaarheid van Ursinus se teologiese opvattings. Verskeie navorsers het daarop gewys dat Ursinus gebruik gemaak het van die teologiese erfenisse uit Zürich, Genève, Wittenberg, die Nederlande en ook van sy eie en andere se werk. Hoewel hy by Melanchton begin studeer het, was Ursinus se dogmatiese opvattings baie duidelik van Calvyn afkomstig. Hierdie opvattings is gevolglik die oorheersende in die Heidelbergse Kategismus. Soos Calvyn, beskou hy die dogmatiese studie as 'n hulpmiddel om die Skrif mee te verstaan en dit kan aanvaar word dat dit ook sy beskouing oor die Heidelbergse Kategismus was. Dit neem egter nie weg dat hy die dogmatiek en die inhoud van die Heidelbergse Kategismus as die samevatting van die Skrifwaarheid beskou het nie, 'n norm vir die ware leer (Heppe 1958: XXXVI). As sodanig het die Heidelbergse Kategismus die Heidelbergse teologie leermatig bepaal en in dié sin kan Ursinus as 'n grondlegger van die Heidelbergse teologie beskou word.

Olevianus se betrokkenheid by die opstel van die Heidelbergse Kategismus is nie volledig bepaalbaar nie. Dit word algemeen aanvaar dat hy verantwoordelik is vir die toevoeging tot $V$ raag 80 wat handel oor die onderskeid tussen die nagmaal en die Roomse mis. Hierdie toevoeging is bykans 'n woordelikse aanhaling uit Art 16 van Calvyn se Confession de la Foy van 1537 (O S 1, 423). Verder word aanvaar dat Olevianus veral meegehelp het in die formulerings oor die sakramente. Sy invloed is ook op te merk in die ordening van sake in die Heidelbergse Kategismus asook die vrae oor die kerklike tug. Olevianus het ook kritiek teen die Heidelbergse Kategismus gehad. Hy wou hê dat Calvyn die Heidelbergse Kategismus eers resenseer voordat dit aanvaar word en het skerp kritiek uitgeoefen op die antropologies-analitiese neiging in die eerste vraag (Esser 1987). Uit hierdie enkele raakpunte word reeds duidelik wat Olevianus se uitgangspunt was wat later in die ontwikkeling van sy verbondsleer sterk na vore gekom het, naamlik die eer van God.

$\mathrm{Na}$ die aanvaarding van die Heidelbergse Kategismus was dit veral Ursinus wat in gesprek (Maulbronner Gespräch April 1564) en geskrif die Heidelbergse Kategismus verdedig en uitgele het (Corpus doctrinae orthodoxae sive catecheticanum explicationum, Heidelberg 1598). Daarmee het hy meegehelp tot die uiteindelike aanvaarding op die ryksdag van Augsburg 1566. 
Olevianus wat die man van die praktyk was, het op sy beurt gestalte gegee aan kerk en teologie in die Palts deur sy hulp by die opstel van 'n nuwe kerkorde wat op 15 November 1563 aanvaar en deur die keurvors onderteken word. Wat Ursinus in woord en geskrif vir die Heidelbergse teologie beteken het, het Olevianus in die praktyk beteken. Hy het 'n besondere belangstelling in die kerklike tug gehad. Die probleem waarmee Heidelberg te kampe gehad het, was dat die kerkvolk nog hoofsaaklik die Lutherse belydenis aangehang het. Daar was te min predikers en volgens teenstanders van Olevianus het hy gemeen om die saak met die tug te kon oplos. Reeds op 12 April 1560, dus drie jaar voor die aanvaarding van die Heidelbergse Kategismus en die kerkorde het hy by Calvyn die wette van die Geneefse konsistorie aangevra (Wesel-Roth 1954: 45). Calvyn het met groot beskeidenheid die Geneefse gebruike aan Olevianus verduidelik in die verwagting dat dit in Heidelberg wel nuttig sou kon wees. Hy was baie duidelik bedag daarop dat die Geneefse gebruike nie noodwendig vir die Palts nuttig sou wees nie. Uit sy antwoord blyk in elk geval dat Olevianus soos hyself die tug as die keersy van die verkondiging van die regte leer beskou het en nie soseer as 'n dwangmiddel om van andersgelowiges Calviniste te maak nie (Schwarz 1962: 1091-3).

Die gedeeltes in die kerkorde van 1563 wat betrekking gehad het op die kerklike tug, is op die Geneefse voorbeeld gebaseer en kan aan die invloed van Olevianus toegeskryf word. Hy wou in ooreenstemming met die presbiteriaal-sinodale stelsel die kerklike tug in die gesagsfeer van die kerk plaas soos wat dit in die Heidelbergse Kategismus eintlik as vanselfsprekend aanvaar word (H K 83-85). Dit is opmerklik dat Olevianus in hierdie saak voortdurend deur Frederik III ondersteun is (Wesel-Roth 1954: 46).

Olevianus vind egter 'n gedugte teenstander in Erastus. Hierdie saak het die twee geleerdes ook uitmekaar gedryf sodat die eensgesindheid en respek wat aanvanklik tussen hulle geheers het, verander het in wantroue en skerp wedersydse teenstand. Olevianus se bedoeling was om met die selfstandige kerklike tug die selfstandige regering van die kerk onder Christus te vestig om die lewe van die gelowiges in ooreenstemming met hulle belydenis te bring sodat aan God alle eer gegee kan word. In die agtergrond het hier reeds sy opvattings oor die verbond meegespreek want die oboedientia christi activa was vir hom die gelowige se verpligting in die verbond wat by ontstentenis die eer van God skend, die verbond verbreek en uiteindelik die straf van God na vore roep.

Erastus het nie beswaar gehad teen die uitoefening van die tug nie, soos duidelik aangetoon word deur die feit dat hy in 1564 vanweë werkdrukte sy amp as lid van die kerkraad neergelê het. In hierdie stadium is die kerkorde met sy bepalings oor die tug reeds aanvaar. Olevianus het ook reeds duidelik laat blyk wat sy opvattings 
was. Erastus wou egter die tug in die hande van die owerheid sien. Hierdie oortuiging kom voort uit sy besondere beskouing oor kerk en staat waarin die owerheid steeds die algehele gesagvoerder, ook oor die kerk is (Wesel-Roth 1954: 63).

Met die aanvaarding van die kerkorde op 13 Julie 1570 slaag Olevianus slegs gedeeltelik daarin om die presbiteriaal-sinodale stelsel in die Palts te vestig. Die owerheid behou die gesag deur die benoeming van die ouderlinge en deur die finale woord oor die kerklike tug en veral die ban. Die kerklike tug is ingevoer maar nie so selfstandig in die hande van die kerk soos wat Olevianus dit wou gehad het nie. Nogtans het hy hiermee aan die kerk in die Palts 'n afdoende Calvinistiese gestalte gegee. Die feit dat die Heidelbergers nou moes leef soos wat hulle in die Heidelbergse Kategismus bely het, was grootliks aan Olevianus se ywer te danke.

Ursinus het in hierdie stryd 'n tussenposisie ingeneem. Hy het saamgestem dat die tug uitgeoefen moes word om dieselfde redes as die van Olevianus. Hy was ook van mening dat die owerheid wat die tug uitgeoefen het, dit maar op 'n halfhartige en onbevredigende manier hanteer het. Nogtans het hy Olevianus nie gesteun nie, omdat by gemeen het dat die kerklike tug nie in die Palts of iewers anders in Duitsland orde kon bring nie. Verder was hy ook oortuig dat die ban van die kerk nie lank sonder owerheidshulp wettig en nuttig gehandhaaf sou kon word nie (Wesel-Roth 1954: 59).

Ursinus en Olevianus het deur hulle arbeid 'n Calvinistiese vorm en inhoud aan die kerk en die teologie van die Palts gegee. Hulle het daarmee groot bekendheid verwerf. Hulle het egter ook bekend geraak vir hulle leer van die verbond, sodat baie navorsers die latere sogenoemde Foederaltheologie van die sewentiende eeu terugvoer na die twee Heidelbergse teoloë. Ursinus en Olevianus se leer van die verbond was nie hulle eie skepping nie, maar was 'n karaktertrek van die gereformeerde teologie soos dit in Switserland ontstaan het.

Pont (1986: 30-31) toon aan dat die leer van die verbond by die Switserse hervormers saamhang met die verskil in kerkbegrip tussen die Reformatore en die Rooms-Katolieke Kerk. Zwingli het as eerste teoloog gewys op die verbond in sy stryd met die wederdopers. Vir Ursinus en Olevianus is Calvyn en Bullinger se opvattings oor die verbond belangrik.

Calvyn gryp terug na Augustinus vir sy leer van die verbond. Vir hom is die verbond eintlik 'n testament waarmee God eensydig sy genadegawes aan die gelowiges gee. Aanvanklik is daar nie 'n verband tussen verbond en uitverkiesing by Calvyn nie, maar later, veral ná die probleem met Bolsec, bring hy die verbond al meer in verband met die uitverkiesing. Uiteindelik raak sy verbondsleer ondergeskik aan sy uitverkiesingsleer sodat die verbond die raamwerk is waarbinne God met sy uitverkorenes handel. Daarmee wil Calvyn beklemtoon dat die mens se ver- 
lossing alleen berus op die vrye genade van God. Hoewel hy aan die gelowige 'n verantwoordelikheid toesê, het dié verantwoordelikheid nooit die betekenis dat die gelowige van sy kant enige bydrae lewer tot die verbond van God nie (Baker 1980: 196-197).

Bullinger het 'n tweesydige verbond geleer waarin die verbond aan alle ander leerstukke voorafgaan. Volgens hom was die verbond 'n saak waarin beide God en gelowige gebonde was aan die voorwaardes van die verbond. Bullinger stel hierdie voorwaardelike verbond terwyl hy vashou aan die Reformatoriese sola gratia. Hier bestaan natuurlik duidelik 'n spanning. Bullinger probeer daaraan ontkom deur die sola fide en die sola gratia binne die struktuur van die verbond te verstaan. Vir hom begin die verbond by Abraham en word vervul wanneer Johannes begin doop (Pont 1984: 75). Aangesien die verbond vir hom die grondliggende struktuur was waarbinne God homself met die mens in die geskiedenis bemoei, het die verbond ook implikasies vir die gemeenskapslewe. In 'n sekere sin kom Bullinger nie los van die Middeleeuse corpus Christianum-gedagte nie, want vir hom is die geskiedenis van die verbond nie net die geskiedenis van verlossing nie, maar ook die geskiedenis van die Christelike gemenebes. En waar die Hervorming die heroprigting van die verbond beteken het, het dit ook ingehou dat die strukture van die verbondsgemeenskap hernu moes word. Dit het vir Bullinger se begrip ook 'n soewereine owerheid ingesluit. Die gevolg was dat hy nie so daarop gesteld was dat die kerk onafhanklik van die owerheid moes bestaan nie en kon Erastus in hom 'n geesgenoot vind in sy stryd teen Olevianus oor die kerklike tug.

Teen hierdie agtergrond van Calvyn en Bullinger moet Ursinus en Olevianus se beskouings oor die verbondsteologie gesien word. Die verbond was 'n belangrike aspek van Ursinus se teologie. Ursinus leer dat God aanvanklik met die mens 'n natuurverbond of ' $n$ werkverbond in die paradys gesluit het. Die inhoud hiervan is dat God aan die mens verlossing beloof in 'n verbond waarin die mens aan God gehoorsaam sal wees. Die wet word verstaan as iets wat in die mens ingegrif is. Hier is nie sprake van verdienste nie maar van God se vrye genade.

Die werkverbond word vervang met die genadeverbond, die verbond in Jesus Christus. Christus is die Middelaar van die genadeverbond en daarin is die gelowige aangewese op die verdienste van Christus. By albei verbonde is die verlossing gratis maar telkens op ' $n$ ander manier. In die genadeverbond is die gelowige verplig tot boete en berou. Ursinus voeg die sakramente hier by. Die sakramente is nie alleen die getuienis van wat God vir die gelowige doen nie maar ook die getuienis van wat die gelowige in verbondsgehoorsaamheid behoort te doen (Schilder 1977: 14-15).

Dit is duidelik dat daar by Ursinus se leer oor die verbond verskeie onopgeloste vrae bestaan. Dit skyn asof daar vir hom geen grens bestaan voor en na die 
sondeval insoverre dit die mens se kennis van die morele wet betref nie (Schilder 1977: 14). Miskien sou 'n mens in hierdie opsig kan verwys na sy verbondenheid aan Calvyn wat die dekaloog gelykstel met die sedewet en ook leer dat die dekaloog in die mens ingegrif is, maar ná die sondeval op 'n gebrekkige manier tot geldigheid kom.

Vervolgens leer Ursinus, hoewel hy vashou aan die vrye genade van God, tog in 'n mate ' $n$ voorwaardelike verbond. Die voorwaardes is onder die natuurverbond vervat in die eis tot gehoorsaamheid en onder die genadeverbond in die eis tot berou en boete. Die grootste spanning ontstaan egter wanneer Ursinus sy verbondsleer nie in verbinding bring met sy uitverkiesingsleer nie. Hy leer 'n streng dubbele uitverkiesingsleer waarin God sommige uitkies en ander verdoem. Dit bring onmiddellik die vraag na vore wat dan die sin van 'n voorwaardelike verbond is (Baker 1980: 202-203). Ursinus gee nie hierop 'n antwoord nie. Hierdie vrae toon egter aan dat Ursinus as hervormer van die derde geslag die teologiese opvattings van drie van sy leermeesters naamlik Melanchton, Bullinger en Calvyn probeer saamvat in 'n geheel, terwyl hy probeer om hulle verbondenheid aan die Skrif te handhaaf.

Olevianus se verbondsleer was vry van sulke dubbelsinnighede. Hy sit sy gedagtes uiteen in die geskrif, De substantia foederis gratuiti inter Deum et electos ... , wat eers na sy dood in 1585 deur Beza in Genève uitgegee word. Dit was die eerste sistematiese uiteensetting van die Calvinistiese verbondsleer en was daarom baie belangrik vir die ontwikkeling van die verbondsteologie. Hierdie uiteensetting van die verbond gee hy as ' $n$ verklaring van die geloofsbelydenis.

Soos Ursinus stel Olevianus dat daar twee verbonde is. Die eerste is die verbond van die skepping wat ná die sondeval die natuurlike verbond of die verbond van die wet word. Die mens wat met die sondeval die imago Dei verloor, word in die verbond van die wet deur God verbind tot 'n volmaakte gehoorsaamheid aan die wet, wat die wet van die natuur of die dekaloog is. Niemand kon hierdie verpligting nakom nie. Daarop gee God 'n tweede onvoorwaardelike genadeverbond wat volledig berus op God se genade en waaraan geen voorwaarde verbonde is waaraan die mens moet voldoen nie. Hierdie genadeverbond wat in wese soos by Calyyn 'n eensydige testament is (Baker 1980: 205), kom slegs toe aan God se uitverkorenes. Slegs aan hulle, maar aan hulle almal word die twee dele van die verbond beloof, naamlik die vergewing van sondes en vernuwing na die beeld van God. Die wese van die verbond bestaan dus daarin dat God Homself skenk as God soos Hy beloof het, 'n God wat nie toorn nie, maar sy uitverkorenes as sy kinders en erfgename aanneem. Dit geskied uit die vrye genade van God sonder enige verdienste van die mens. Die verbond word deur Woord en sakrament bedien as 'n roeping uit die 
duisternis waarin sowel wet as evangelie aangekondig word (Geschriften 1963: 130131).

Soos by Calvyn is die genadeverbond by Olevianus gebaseer op God se uitverkiesing. Geloof speel hier 'n sekondêre rol, aangesien dit uit genade geskenk word aan die wat tevore uitverkies is. Die genadeverbond word as testament eers geldig as die testator te sterwe kom. Christus bevestig met sy dood die ewige genadeverbond as Hy daardeur die ou Sinaïverbond vervang en die wet van $\mathrm{G}_{g}$ in die harte van die uitverkorenes skryf. Anders as Calvyn, verbind Olevianus dus die verbond ook met die etiek. In die plek van voorwaardes kom die dankbaarheid van die uitverkorenes te staan. Die einddoel van die verbond is die eer van God en die heilssekerheid van die uitverkorenes.

Die leer van die verbond het so 'n belangrike plek ingeneem in die teologie van Ursinus en Olevianus dat dit baie opvallend is dat daar min van die verbondsgedagte in die Heidelbergse Kategismus na vore kom. Vraag 74 maak uitdruklik daarvan melding wanneer die kinderdoop ter sprake kom en so ook Vraag $\mathbf{8 2}$ waar oor die deelname aan die nagmaal gehandel word. Metz en andere fouteer dus as hulle die verbondsteologie slegs tot Vraag 74 beperk (Metz 1985: 584). Schilder meen dat die verbondsteologie nie in die gereformeerde belydenisskrifte voorkom nie, omdat daar by die Reformatore tydens die ontstaan van die belydenisse nog nie heeltemal sekerheid oor die verbondsleer was nie (Schilder 1977: 7).

Wat die Heidelbergse Kategismus betref, word die verbondsleer inderdaad nie as 'n afsonderlike leerstuk behandel nie. 'n Mens sou egter grootliks fouteer indien die betekenis daarvan uit die oog verloor word dat Vrae 74 en 82 te doen het met wie die sakramente mag gebruik. Deur die wettige en korrekte gebruik van doop en nagmaal met die verbond te begrond, word die hele sakramentsleer van die Heidelbergse Kategismus teen die agtergrond van die verbondsleer geplaas. Die sakramente is dus slegs bedoel vir diegene met wie God sy verbond gesluit het.

Dit is opmerklik dat die verbond terselfdertyd in Vraag 82 met die tug verbind word. Daardeur word 'n verband gelê met die uitverkiesingsleer wat andersins ook nie in die Heidelbergse Kategismus na vore kom nie. Hierdie verband dui onmiskenbaar op die invloed van Olevianus in die Heidelbergse Kategismus aangesien Ursinus verbond en verkiesing nie byeenbring nie. Vermoedelik sou dieselfde verbande gevind word in die doop-en nagmaalsformulier wat aan weerskante van die Heidelbergse Kategismus in die kerkorde van 1563 opgeneem is.

Die verbondsteologie van Ursinus en Olevianus het 'n nawerking gehad in die algemene aanvaarding daarvan in die Calvinistiese ortodoksie van die laat sestiende-, begin sewentiende eeu. dit was veral die leer van die dubbele verbond wat in die Calvinistiese ortodoksie die ekwivalent was van die Lutherse wet en evan- 
gelie. Vanaf Heidelberg het die verbondsleer veral deurgewerk na Nederland. Franciscus Junius, 'n kollega van Ursinus, begin sy professorale leeropdrag te Heidelberg in 1584 met drie redes oor die verbondsteologie. Deur sy optrede het die Heidelbergse fakulteit die setel geword waar die leer van die dubbele verbond as wetenskap bevorder is. Sy leerling Franciscus Gomarus, dra die leer van die dubbele verbond oor na Nederland in 1594 in sy professorale intreerede te Leiden getiteld, De foedere Dei. Hy beskryf die dubbele verbond met die begrippe foedus naturale en foedus supranaturale waarin reeds sy supralapsaristiese standpunt na vore kom, aangesien hy soos Olevianus beide in die leer van die uitverkiesing begrond (Goeters 1983: 248). Dat die wese van die verbondsleer hiervandaan na die Dordtse sinode deurgewerk het, is bekend.

Dit is moeiliker en waarskynlik onmoontlik om aan te toon dat Coccejus en sy skool reglynig van Ursinus en Olevianus afhanklik was. Bullinger sou hier waarskynlik eerder in die prentjie kom.

\section{SLOTOPMERKINGS}

Olevianus en Ursinus het met hulle teologiese en kerkordenende arbeid eenvormigheid in die kerk en teologie van die Palts gebring. Die Heidelbergse Kategismus kan beskou word as die samevatting van die Heidelbergse teologie. Die werking van die Heidelbergse Kategismus strek ver oor die landsgrense van Duitsland tot in die meeste gereformeerde kerke in die wêreld. Dit mag dalk die moeite loon om vas te stel watter invloed die 1563-kerkorde van die Palts uitgeoefen het op die Konvent van Wesel aangesien Petrus Dathenus wat as voorsitter by die konvent opgetree het, baie nou met Olevianus saamgewerk het in die stryd om die presbiteriale stelsel in die Palts in te voer.

Olevianus en Ursinus se verbondsleer het die wegspringpunt gevorm vir die latere Foëderaltheologie. Hulle het die Skrifteologie van Calvyn in dogmatiese leerstellings verwoord sonder om daarmee geslote leersisteme op te bou. As sodanig vorm hulle die brug van die Skrifteologie na die latere Calvinistiese skolastiek van die sewentiende eeu, egter sonder om die filosofies-spekulatiewe voorwaardes te verskaf wat die skolastiek gekenmerk en die kwaliteit van die teologie verswak het.

Literatuurverwysings

BAKER, JW 1980. Heinrich Bullinger and the Covenant. Athens, Ohio: Ohio University Press.

CALVIN, J s a. Opera selecta, I. München: Kaiser. 
ESSER, HH - STEENKAMP, JJ 1987. Horstmar.

FRANZ, G 1987. Caspar Olevian. Trier: Universitäsbibliothek.

GESCHRIFTEN VAN CASPAR OLEVIANUS 1963. Den Haag: Het Reformatorische Boek.

GOETERS, JFG 1983. Föederaltheologie. TRE, $B d X I$.

HEPPE, H 1958. Die Dogmatik der evangelisch-reformierten Kirche. 2. Aufl. Neukirchen: Neukirchener Verlag.

METZ, W 1985. Heidelberger Katechismus. TRE, Bd XIV.

PONT, AD 1984. Die kinderdoop en die verbond by die reformatore Zwingli en Bullinger: 'n Kort oorsig. HTS 40/3, 68-78.

PONT, AD 1986. Verbond en volkskerk. HTS 42, 30-31.

SCHAFF, P 1919. The creeds of Christendom. Vol I. New York: Harper.

SCHILDER, K 1977. Het verbond in de gereformeerde symbolen. 5de dr. Kampen: Copieerinrichting vd Berg.

SCHWARZ, R 1962. Johannes Calvins Lebenswerk in seinen Briefen. Bd 3. Neukirchen: Neukirchener Verlag.

WESEL-ROTH, R 1954. Thomas Erastus. Lahr: Moritz Schauenburg. 